\title{
VÝVOJ A ADAPTABILITA REGIONÁLNÍCH EKONOMIK V ČESKÉ REPUBLICE V POSTTRANSFORMAČNÍM OBDOBÍ
}

\section{DEVELOPMENT AND ADAPTABILITY OF REGIONAL ECONOMIES IN THE CZECH REPUBLIC IN POST-TRANFORMATION PERIOD}

\author{
Ing. Petr hLAVÁČEK, Ph.D. \\ Katedra regionálního a lokálního rozvoje $\mid$ Department of Regional and Local Development \\ Fakulta sociálně ekonomická Faculty of Social and Economic Studies \\ Univerzita Jana Evangelisty Purkyně v Ústí n.Labem Jan Evangelista Purkyně University in Ústí n.Labem \\ $\triangle$ Moskevská 54, 40096 Ústí nad Labem, Czech Republic \\ E-mail: petr.hlavacek@ujep.cz
}

\begin{abstract}
Anotace
Ve výzkumu regionálního rozvoje se aktuálně hovoři o významu regionální adaptability, tedy schopnosti regionálního prostředi implementovat nové ekonomické impulsy a tlumit negativní ekonomické a sociálni dopady, zvláště v obdobi ekonomické krize. Výzkumným cílem článku je zjistit, $z d a$ se divergenčni tendence $v$ řadě socioekonomických parametrů projevuji $i$ v odlišném inovačním vývoji regionů. Silnějši regionální adaptabilita je patrná v Praze, Středočeském a Plzeňském kraji. Moravskoslezský a Ústecký kraj naopak po ekonomické stagnaci v devadesátých letech prochází určitým oživením ekonomik, proto lze považovat adaptabilitu těchto ekonomik za vyšší, než v prípadě krajů Olomouckého, Vysočiny nebo Karlovarského, kde se projevuje slabši regionálni adaptabilita a nižší intenzita vývojových změn.
\end{abstract}

\section{Klíčová slova}

regionální adaptabilita, inovace, regionálni ekonomika, Česká republika

\section{Annotation}

Capability of the regional environment to implement new economic impulses and to soften negative economic and social impacts is currently considered in the research of the regional development, especially in the time of economic crisis. The research goal of this paper is finding out whether the divergence tendencies seen in social-economic parameters are reflected in different innovation development of regions. Better adaptability of the regions is obvious in Prague, Central Bohemian Region and Plzeñ Region. On the other hand, the Moravian-Silesian Region and the Ústí Region, following economic stagnation in the 1990s, revive their economies to a certain extent and therefore, their resilience is much higher than of Olomouc Region, Vysočina Region, Karlovy Vary Region where the regional adaptability is weaker and the intensity of the development changes is lower.

Key words

regional adaptability, innovation, regional economy, Czech Republic

JEL classification: $R 11,018, P 25$

\section{Teoretická východiska, cíle, metoda}

V současném výzkumu v oblasti regionálního rozvoje je podle konceptů, jako jsou regionální inovační systémy (Bathelt, Malmberg, Maskell 2004; Asheim, Coenen 2006, Tödtling, Trippl 2007), innovative milieu (napřr. Rutten, Boekema 2007), úspěšnost aktérů významně determinována prostředím, kde daný aktér působí. Z pohledu rozvoje české ekonomiky se jedná o aktuální teoretické přístupy, nebot' vymezují i nové pohledy na problematiku posttransformačního období na úrovni makroekonomické a 
mikroekonomické, resp. národní, regionální a lokální. Ve výzkumu regionálního rozvoje se společně s regionální konkurenceschopností (Huggins, Williams 2011, Wokoun 2009) v důsledku ekonomické krize hovoří také o regionální adaptabilitě (Hassink 2010, Pike, Dawley, Tomaney 2010), tj. schopnosti regionálního prostředí implementovat nové ekonomické impulsy a tlumit negativní ekonomické a sociální dopady. Přínos analýz vybraných regionů pak spočívá v syntetickém přístupu, který může využivat například výše uvedené teorie pro vysvětlení růstu nebo stagnace některých regionálních ekonomik.

V analýze regionální adaptability je možné použít konstrukci multifaktorových indexů, které se aplikují pro komparaci vývoje území, regionů nebo států. Př́ikladem analýzy regionální odolnosti je tzv. Resilience Capacity Index, publikovaný universitou v Berkeley, který používá větší počet atributů z oblasti regionálně ekonomické, socio-demografické a komunitně-infrastrukturní. Každá z uvedených oblastí je složena z několika dílčích ukazatelů, př́ípadně z komponent jiných indexů. V oblasti regionálně ekonomické je použita suma komponent $\mathrm{z}$ tzv. inovačního indexu, který pracuje se souborem dat z oblastí lidského kapitálu a ekonomicko-technologického rozvoje. Vybrané indikátory z výpočtu Resilience Capacity Index jsou použita v tomto článku pro posouzení vývojových změn na úrovni krajů České republiky.

V tranzitivních ekonomikách je reakce regionálních vývojových procesů podstatnější, protože evolučně probíhající procesy jsou oproti situaci v regionech západní Evropy zároveň indikátorem úspěšnosti ekonomické transformace. Vznikají nové vývojové trajektorie, které mohou v některých př́padech vést k ekonomickému zaostávání, stagnaci nebo iniciaci dlouhodobých divergenčních vývojových procesů.

Př́kladem může být schopnost integrovat zahraniční investory do regionální ekonomiky (Hlaváček, Koutský 2011). Zahraniční investice formují nové ekonomické prostředí s vyšší konkurenceschopností na tuzemském i zahraničním trhu, které kvalitativně převyšuje hostitelskou ekonomiku. Pravděpodobnost vzniku a velikosti duality (rozdílu ve výkonnosti původních a nových ekonomických struktur) souvisí s mírou adaptability regionu, tj schopnosti se přizpůsobit novým podmínkám a eliminovat (př́padně výrazně tlumit) dopady externích vývojových procesů. Regionální adaptabilita se $\mathrm{v}$ prípadě zahraničních investic projevuje $\mathrm{v}$ míře duality ekonomického prostředí regionu. Neschopnost regionu adaptovat se na nové podmínky vede ke vzniku duální ekonomiky, způsobené horší schopností místních firem se subdodavatelsky provázat s příchozími zahraničními investory.

Výzkumným cílem je zachytit a analyzovat vývojové trajektorie regionů v České republice. Výzkumné zaměření vyplývá ze skutečnosti, že ekonomický vývoj je v mnoha ohledech významně provázán se sociálním vývojem a vyvolává diferencované reakce na úrovni regionů (viz např. Blažek, Csank 2007). Cílem je zjistit, zda se divergenční tendence vybraných socioekonomických parametrů projevují i v odlišném inovačním vývoji regionů. Lze totiž očekávat, že nové vývojové tendence, zejména $\mathrm{v}$ aktivitách $\mathrm{s}$ vysokým inovativním potenciálem, budou ještě více posilovat asymetrii v rozvojových procesech na regionální úrovni, a tím více zdůrazňovat polarizační rizika divergence v nosných oblastech ekonomiky (např. v oblasti inovací), které mají strategický význam pro posílení regionální konkurenceschopnosti.

Reakce regionů, individuální předpoklady a schopnosti regionálního prostředí tlumit negativní ekonomické a sociální dopady, jsou spojené s regionální úrovní regionální adaptability. Podobně jako národní tranzitivní ekonomiky prošly $\mathrm{v}$ devadesátých letech vlastním průběhem ekonomické transformace, je možné sledovat odlišné vývojové trajektorie na úrovni jednotlivých regionů. $\mathrm{V}$ extrémním př́padě mohou vést externí ekonomické vlivy k ekonomickému zaostávání, stagnaci a iniciaci dlouhodobých divergenčních vývojových procesů a celkovému lock-inu vývoje regionální ekonomiky.

Identifikace a monitoring vývojových procesů je primárním předpokladem pro formování opatření na národní a regionální úrovni, mající za cíl tlumit negativní dopady a posilovat regionální odolnost a 
adaptabilitu regionů v neustále se měnícím ekonomickém prostředí. Podle Bristowa (2010) je regionální odolnost také relevantním východiskem pro koncipování regionální rozvojové strategie. Analýzy regionálních rozdílů lze také využít pro tvorbu regionálních politik (Viturka 2010) nebo v regionálním a městském marketingu, který popisuje např. Ježek (2011).

Pro analýzu regionálních vývojových procesů je vhodné využít škálu ukazatelů a indikátorů, které jsou dostatečně reprezentativní a zároveň jsou dlouhodobě statisticky sledovány. Rizikem volby co nejširšś skupiny indikátorů může být určitá nivelizace výsledků analýzy, způsobená agregátním hodnocením dat s různou mírou reprezentativity. V článku bude použita skupina vybraných ukazatelů, které dostatečně popisují hlavní vývojové změny ve vybraných oblastech transformace regionální ekonomiky. Do prvního analyzovaného okruhu dat patří ukazatele vycházející z hlavních makroekonomických ukazatelů, druhá skupina šetřených ukazatelů vychází z oblasti kritérií sledujících inovační potenciál regionu.

V oblasti makroekonomických dat byl využit soubor ukazatelů, přičemž prvním je vývoj hrubého domácího produktu na obyvatele a jeho rozdíl mezi počátkem a koncem sledovaného období let 2001 - 2009. Pro hodnocení vývojových trajektorí́ poskytuje analýza vývoje HDP na počet obyvatel ve sledovaném období poměrně reprezentativní pohled na sledování ekonomického vývoje regionu.

Dalším použitým ukazatelem v této oblasti je př́liv zahraničních investic v letech 2001-2009, který poukazuje na investiční atraktivitu jednotlivých regionů. V této subkategorii je sledován kumulovaný př́liv zahraničních investic za roky 2001-2009 přepočtený na ekonomicky aktivní obyvatele. Význam uvedeného kritéria (součtu ročních objemů zahraničních investic za období let 2001-2009) spočívá v odstranění vlivu ročních výkyvů v prŕilivu přímých zahraničních investic, který je do značné míry spojen s průběhem hospodářského cyklu globální ekonomiky. Tvorba investic je v České republice úzce provázána s prŕlivem zahraničních investic, tj. podniků pod zahraniční kontrolou. Jejich role pro růst české ekonomiky je vnímána jako podstatná, v některých odvětvích zastoupení zahraničních výrobců v produkci nebo zaměstnanosti dnes převládá nad tuzemskými firmami.

Regionální trh práce (dopady ekonomické krize na trh práce se také zabýval např. Toušek, Novák 2011) reprezentuje ukazatel míry nezaměstnanosti a změn mezi rokem 2001 a 2009. Tento ukazatel indikuje schopnost regionálního prostředí adaptovat se na probíhající socioekonomické procesy, vytvářet nová pracovní místa, př́ípadně nacházet uplatnění na regionálních trzích práce. Dalším ukazatelem poukazující na vývoj ekonomického potenciálu krajů je ukazatel průměrných mezd a jejich přirůstku za sledované období let 2001-2009, protože růst hrubých měsíčních mezd je odvislý od úrovně ekonomické rozvinutosti kraje a ziskovosti místních firem. Groot, Möhlmann, Garretsen, de Groot (2011) při analýze citlivosti regionů na krizi sledují také vývoj mzdových nákladů. Posledním sledovaným ukazatelem je komparace vývoje počtu obyvatel krajů mezi roky 2001 a 2009. Význam zařazení tohoto ukazatele spočívá v omezení vlivu emigrace obyvatel na vývoj míry nezaměstnanosti, nebot' emigrace EA osob do jiných regionů se projevuje i na poklesu míry nezaměstnanosti, což je príklad zejména Moravskoslezského kraje.

Druhou sledovanou oblastí, v jejímž rámci byly provedené komparace vývojových procesů, byla oblast inovací. V konceptu regionálního inovačního systému, triple helix (Leydesdorff, Zawdieb 2010, Etzkowitz, Leydesdorff 2000, Brostrom 2011) je inovační potenciál a schopnost tvorby inovací považován za klíčový indikátor růstu regionální ekonomiky. Pro tuto kategorii bylo vybráno několik druhů ukazatelů. První ukazatel analyzuje vývoj zaměstnanosti ve vědě a výzkumu a to $z$ hlediska př́růstku nebo poklesu počtu zaměstnanců $\mathrm{VaV}$ v letech 2005-2009, což ukazuje na schopnost regionů vytvářet kvalifikovaná pracovní místa spojená s vývojem inovací.

Další ukazatel sleduje změny v objemu výdajů na $\mathrm{VaV}$ mezi roky 2005 a 2009, které byly vynaloženy $\mathrm{v}$ jednotlivých regionech ČR, do výpočtu byly zahrnuty výdaje na $\mathrm{VaV}$ z veřejných a ze soukromých zdrojů. 
Regionální rozdíly v institucionálních strukturách sleduje ukazatel vývoje počtu inovativních podniků, u kterého byla $\mathrm{z}$ důvodu omezenosti informací použita data, sledující prírůstek inovativních podniků z období let 2004 a 2008. Poslední ukazatel, který byl zařazen do této kategorie, byl vypočten $\mathrm{z}$ růstu podílu osob v regionu s ukončeným terciálním vzděláním mezi roky 2005 a 2009, to poukazuje na schopnost regionálního trhu práce vytvářet pracovní pozice s vyššími nároky na kvalifikaci, což lze považovat za indikátor ekonomického a také inovačního rozvoje regionu.

Soubor dat za makroekonomickou a inovační oblast byl za účelem jejich komparace nejprve standardizován. Nejdříve byl spočítán průměr za jednotlivé ukazatele, společně se směrodatnou odchylkou, která byla použita pro získání kladných a záporných hodnot za jednotlivé kraje, kde kladné číslo znamená nadprůměrnou hodnotu a záporné číslo podprůměrnou hodnotu v komparaci s průměrem za př́slušnou oblast.

\section{Vývojové trendy regionálních ekonomik v ČR}

Nejprve byly sledovány vybrané hlavní makroekonomické ukazatele. Tabulka č. 1 zaznamenává vypočtená data a jejich změny mezi roky 2001 až 2009. Objem zahraničních investic dosažený mezi roky 2001 a 2009 byl nejvyšší v Praze. Výrazně vyšší hodnoty, oproti ostatním krajům v ČR, jsou spojené také se Středočeským krajem. Komparace ostatních regionů s Prahou je v př́padě př́livu zahraničních investic poměrně nevhodná, nebot' Praha je jako hlavní město se sídly centrál poboček zahraničních firem $\mathrm{v}$ odlišném postavení. Nejnižší objem př́mých zahraničních investic je zaznamenaný v Olomouckém, Královéhradeckém a Zlínském kraji, kde dosahuje zhruba třetiny objemu prŕmých zahraničních investic na obyvatele ve Středočeském kraji.

\section{Tab. 1: Vývoj makroekonomických ukazatelů regionů v ČR}

\begin{tabular}{|l|r|r|r|r|r|}
\hline Region & IFDI 01/09 & IWG 01/09 & IUNEM01/09 & IPOP 01/09 & IHDP09/01 \\
\hline Jihočeský & 783 & 51,3 & $-1,8$ & 2,1 & 43 \\
\hline Jihomoravský & 628 & 60,9 & $-0,9$ & 1,8 & 55 \\
\hline Karlovarský & 525 & 49,8 & $-2,4$ & 1,3 & 28 \\
\hline Královéhradecký & 426 & 55,9 & $-1,7$ & 0,9 & 37 \\
\hline Liberecký & 860 & 55,5 & $-3,9$ & 2,7 & 19 \\
\hline Moravskoslezský & 765 & 52,2 & 3,0 & $-1,1$ & 57 \\
\hline Olomoucký & 410 & 57,5 & $-0,4$ & $-0,1$ & 45 \\
\hline Pardubický & 639 & 57,0 & $-1,7$ & 1,8 & 48 \\
\hline Plzeňský & 838 & 57,4 & $-1,6$ & 4,1 & 38 \\
\hline Praha & 5864 & 42,5 & $-0,3$ & 7,7 & 60 \\
\hline Středočeský & 1253 & 57,0 & $-0,3$ & 11,0 & 48 \\
\hline Ústecký & 866 & 56,3 & 2,2 & 2,0 & 51 \\
\hline Vysočina & 718 & 57,8 & $-3,2$ & 0,7 & 33 \\
\hline Zlínský & 488 & 51,8 & $-2,3$ & $-0,5$ & 51 \\
\hline
\end{tabular}

IFDI - kumulovaný príliv PZI na obyvatele v letech 2001 a 2009

IUNEM - pokles miry nezaméstnanosti v letech 2001 a 2009

IPOP - príruistek obyvatel

IWG - príristek hrubé mzdy mezi roky 2001 a 2009

IHDP - príruistek HDP na obyvatele mezi roky 2001 a 2009.

Index růstu hrubých mezd mezi roky 2001 a 2009 patří mezi ukazatele s nižší mírou variability. Poměrně překvapivé je zjištění, že v Praze rostla průměrná mzda mezi regiony nejméně, což vyplývá $\mathrm{z}$ dlouhodobě vyšší úrovně průměrné mzdy $\mathrm{v}$ tomto regionu. $\mathrm{K}$ nižšímu tempu růstu hrubých mezd mezi roky 2001 a 2009 dochází také v Karlovarském $(+49,8)$, Jihočeském $(+51,3 \%)$ a Zlínském kraji $(51,8 \%)$. Naopak nejvyšší nárůst hrubých mezd je dosažen v Jihomoravském kraji $(+60,9 \%)$. 
Index vývoje míry nezaměstnanosti mezi roky 2001 a 2009 ukazuje v případě kladných čísel pokles míry nezaměstnanosti a u záporných hodnot naopak na trend růstu nezaměstnanosti. Vypočtené hodnoty ukazují na schopnost strukturálně postižených regionů, které jsou obecně považované za regiony se zastaralým průmyslovým potenciálem, snižovat míru nezaměstnanosti. $\mathrm{V}$ těchto regionech, tj. v Moravskoslezském a v Ústeckém kraji, došlo k nejvyššímu poklesu míry nezaměstnanosti, což je nutné vidět v kontextu původních hodnot na počátku sledovaného období, kdy její hodnota výrazně překračovala ostatní kraje v ČR. Naopak hospodářsky zaostávající regiony s nízkou hustotou osídlení, se vyznačují nadprůměrným růstem míry nezaměstnanosti např. v kraji Vysočina nebo ve Zlínském kraji. Poměrně překvapivý je růst míry nezaměstnanosti v Libereckém kraji, který byl v mezikrajském srovnání nejvyšší. V krajích s dlouhodobě nízkou mírou nezaměstnanosti nedochází k výraznějším změnám.

Tab. 2: Vývoj inovačního potenciálu regionů v ČR

\begin{tabular}{|l|r|r|r|r|}
\hline Region & ILAB $09 / 05$ & ITER09/05 & IEXP 09/05 & IEN 08/04 \\
\hline Jihočeský & 20,7 & 2,9 & 31,9 & 85,1 \\
\hline Jihomoravsḱ́ & 18,8 & 3,0 & 74,6 & 104,0 \\
\hline Karlovarský & 21,2 & 1,3 & 21,1 & 169,4 \\
\hline Královéhradecký & 29 & 2,9 & 41,2 & 56,4 \\
\hline Liberecký & 6,1 & 1,2 & 19,7 & 44,2 \\
\hline Moravskoslezský & 37,8 & 2,9 & 38,9 & 73,8 \\
\hline Olomoucký & 8,3 & $-0,5$ & 18,1 & 27,4 \\
\hline Pardubický & 20,2 & 1,9 & 18,8 & 121,9 \\
\hline Plzeňský & 17,7 & 3,2 & 41,5 & 109,3 \\
\hline Praha & 11 & 3,6 & 32 & 51,5 \\
\hline Středočeský & 17,5 & 2,9 & 17,4 & 83,1 \\
\hline Ústecký & 31,3 & 0,7 & 10,7 & 121,7 \\
\hline Vysočina & 7,1 & 1,5 & $-8,6$ & 102,1 \\
\hline Zlínský & 6,6 & 2,3 & 0,8 & 46,1 \\
\hline
\end{tabular}

ILAB - rùst počtu zaméstnaných ve VaV mezi roky 2005-2009

IEXP - růst výdajů na VaV mezi roky 2005 a 2009

IEN - rüst počtu inovativnich podniku mezi roky 2004 a 2008

ITER - rüst počtu podílu osob s ukončeným terciálním vzdéláním v populaci mezi roky 2005 a 2009

Zdroj: vlastni výpočty na základě dat z ČSÚ

V populačním přírůstku jednoznačně dominují mezi kraji v České republice Praha a Středočeský kraj, kdy se v růstu Středočeského kraje výrazně projevuje jeho pozice v zázemí Prahy a společně vytváŕí nejvíce migračně atraktivní region v České republice.

Nejvíce vzrostl HDP v Praze, následované Moravskoslezským a Jihomoravským krajem, naopak nejnižší př́růstek HDP byl zaznamenán v Libereckém a Karlovarském kraji a na Vysočině. Z vývoje HDP v mezikrajském hodnocení je patrné, že vyššího růstu dosahovali kraje s vyšší úrovní HDP na obyvatele a staré průmyslové regiony. Vývojové procesy z hlediska vývoje HDP mezi roky 2001 a 2009 potvrzují pokračující divergenční procesy mezi nejméně a nejvíce rozvinutými regiony v ČR.

V oblasti hodnocení vývoje inovačního potenciálu regionů se analyzovaly změny v oblasti lidských zdrojů, výdajích na vědu a výzkum a změny v počtech inovativních podniků. Index vývoje počtu zaměstnaných osob ve $\mathrm{VaV}$ ukazuje nejvyšší nárůst v Moravskoslezském kraji, kde se jejich počet zvýšil mezi roky 2005 a 2009 o 37,8\%. Na druhém místě se ocitl Ústecký kraj, následovaný Karlovarským krajem. Důvodem intenzivnějšího růstu uvedených krajů (v komparaci s ostatními kraji) je skutečnost, že v obou krajích byla v roce 2005 tato skupina pracovníků velmi málo početně zastoupena. Nárůst počtu zaměstnanců ve $\mathrm{VaV}$ o stejný počet osob je oproti regionům s větší velikostí souboru $\mathrm{VaV}$ zaměstnanců statisticky významnější. Slabá pozice Prahy je způsobena 
podobnými důvody, kdy se Praha naopak vyznačuje dlouhodobě velkým počet pracovníků ve VaV. Nicméně celkově nižší růstovou dynamiku vykazují kraj Liberecký, Zlínský a Vysočina, kde je zaznamenán výrazně nižší př́růstek zaměstnanců ve VaV oproti jiným krajům. Sledujeme-li změny v podílu osob s ukončeným VŠ vzděláním v populaci, zde je naopak Praha na první pozici, následovaná Plzeňským a Jihomoravským krajem. Můžeme konstatovat, že v př́padě Prahy se silněji projevuje dlouhodobý divergenční trend, což podporuje i nadprůměrný růst Středočeského kraje. Nejnižší př́růstky VŠ vzdělaných osob v populaci mezi roky 2005 a 2009 byly zjištěny u Ústeckého kraje a také Olomouckého kraje, kde dokonce dochází k poklesu podílu těchto osob v populaci.

Další ukazatel, který sledoval růst výdajů na $\mathrm{VaV}$ mezi roky 2005 a 2009 zaznamenal nejvyšší nárůst v Jihomoravském kraji, což je ovlivněné zejména rolí města Brna, které se stává jedním z nejvýznamnějších vědeckovýzkumných center v České republice. Na druhé pozici je Plzeňský kraj, což je obdobný př́ípad jako v Jihomoravském kraji, nebot' zde značně dominuje město Plzeň. Naopak pokles výdajů na VaV nastal mezi roky 2005 a 2009 v kraji Vysočina. Posledním šetřeným ukazatelem byl růst počtu inovativních podniků mezi roky 2004 a 2008. Z důvodu omezené dostupnosti dat byla použita data za kraje v uvedeném období. Tento ukazatel vykazuje velké rozdíly mezi kraji, což je způsobené v některých případech menší velikosti souboru firem v některých regionech, zejména Karlovarského kraje nebo Vysočiny. Nízký růst v Praze nelze hodnotit zcela negativně, nebot' má velmi vysoký počet inovativních podnikủ s výrazným odstupem od ostatních regionů. Naopak Olomoucký kraj, i přes poměrně velký počet inovativních podniků na počátku sledovaného období, vykazuje velmi nízký růst jejich počtu, proto skončil na posledním místě.

\section{Souhrnné hodnocení regionální adaptability}

Cílem rozdělení krajů do skupin bylo vymezit tři velikostně podobné kategorie krajů: a) s vyšší dynamikou ekonomických změn, b) s průměrnou dynamikou, c) s podprůměrnou dynamikou. V první skupině jsou regiony Praha a Středočeský kraj, což jsou regiony s dlouhodobě nadprůměrnou ekonomickou rozvinutostí, které vykazují mezi roky 2001 a 2009 stabilně vyšší rozvoj. Jihomoravský kraj je príkladem regionu s velmi silným a dynamickým centrem růstu v Brně a jeho zázemí, které ovlivňuje výsledky celého kraje. Poměrně překvapivé jsou agregované výsledky za Moravskoslezský a Ústecký kraj, což jsou regiony dlouhodobě považované za strukturálně postižené, ve kterých prochází průmyslová a těžební odvětví dlouhodobou restrukturalizací, např. Rumpel, Slach, Koutský (2010). V porovnání s druhou kategorií hospodářsky zaostalých regionů mají oba regiony i přes strukturální problémy velký ekonomický potenciál. Dobré umístění těchto regionů také dokládají pozitivní výsledky z probíhající ekonomické restrukturalizace regionálních ekonomik.

Nejnižší intenzita ekonomických změn v letech 2001 až 2009 byla zjištěna $v$ krajích, které se vyznačují určitou mírou perifernosti v rámci České republiky. V př́ípadě kraje Vysočina se jedná o vnitřní periferní území v rámci státu, s nižším stupněm ekonomické dynamiky.

V druhé oblasti, zaměřené na hodnocení inovační dynamiky regionů, jsou rozdíly ve struktuře krajů výraznější než v první hodnocené oblasti. V růstu inovační dynamiky mezi roky $2005-2009$ se do první kategorie krajů ( $\mathrm{s}$ vyšším růstem inovační dynamiky) posunul z druhé kategorie Plzeňský a Královéhradecký kraj, zatímco Praha společně se Středočeským a Ústeckým krajem klesla do druhé kategorie. V př́padě Prahy a Středočeského kraje je nutné uvést, že tyto regiony mají ve sledovaných parametrech nadprůměrnou úroveň inovačního potenciálu, naopak Ústecký kraj vychází z výrazně kvantitativně slabší základny, proto se př́ípadný růst intenzivněji projevuje v dosažení relativně vyšších př́růstků. Velmi dobré umístění strukturálně postižených regionů, potvrzuje poměrně úspěšné transformační procesy regionální ekonomiky a zejména její průmyslové základny. 


\section{Obr.1: Agregátní hodnocení krajů podle dynamiky vývojových změn}

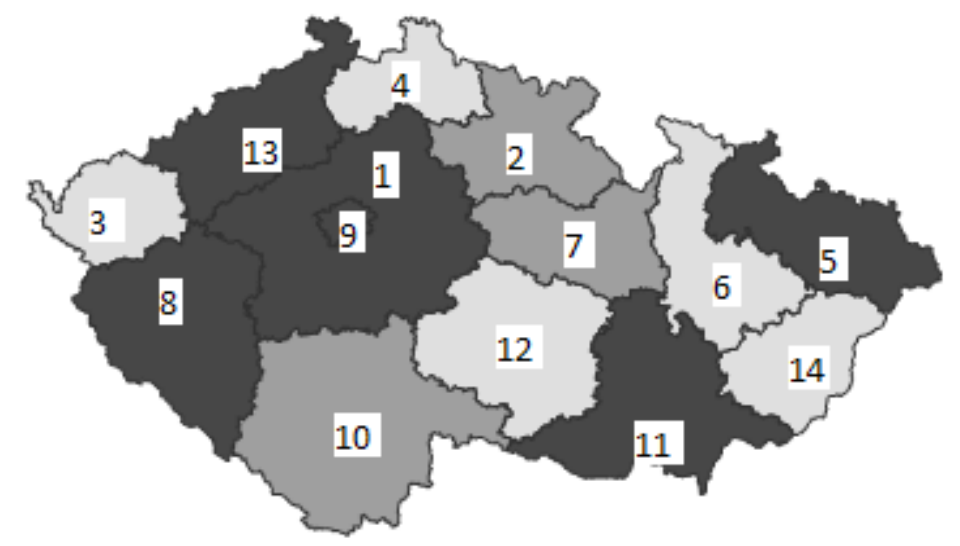

1-Středočeský kraj, 2-Královéhradecký kraj, 3-Karlovarský kraj, 4-Liberecký kraj, 5-Moravskoslezský kraj, 6-Olomoucký kraj, 7-Pardubický kraj, 8-Plzeňský kraj, 9-Praha, 10-Jihočeský kraj, 11-Jihomoravský kraj, 12-Vysočina, 13-Ústecký kraj, 14-Zlinský kraj.

Nižší intenzita makroekonomických vývojových změn se projevuje i v kategorii regionů s nižším růstem inovačního potenciálu, kam patř́ Zlínský, Liberecký, Olomoucký kraj a Vysočina. Obrázek č. 1 ukazuje i určitou míru separace těchto krajů od ostatních regionů v České republice. Tento výsledek poukazuje na slabší potenciál transformačních procesů, které se projevují v nižší míře socioekonomických změn uvedených regionů. Poměrně překvapivé je umístění Libereckého kraje, který je na rozdíl od ostatních regionů více průmyslově orientován, má také dobrou dopravní dostupnost do Prahy a Středních Čech, zejména Mladé Boleslavi se sídlem automobilového koncernu Volkswagen - Škoda, který má v prostoru severovýchodních Čech rozvinutou sít' subdodavatelských firem. I přes tyto rozvojové faktory vykazuje nižší úroveň inovační dynamiky.

Souhrnné hodnocení makroekonomické a inovační intenzity ukazuje na relativní provázanost obou sledovaných oblastí. Na základě uvedeného hodnocení lze vymezit několik hlavních poznatků. Kraje s dlouhodobě nadprůměrně rozvinutou ekonomikou a vyšším hrubým domácím produktem si stále udržují vyšší ekonomický růst, i když růst inovační aktivity není v těchto krajích tak intenzivní. To může být způsobené silnější orientací na terciální sféru, kdy je v těchto krajích vývoj průmyslové základny poměrně omezen (zejména $\mathrm{v}$ Praze). Růst Prahy se současně nepř́mo přenáší do Středočeského kraje, který v podstatě vytvář́ socioekonomické zázemí Prahy a oba kraje společně vytvárí hlavní růstový makroregion v České republice. Velmi dobrých výsledků dosahuje Jihomoravský kraj, jak v oblasti růstu makroekonomických dat, tak i ukazatelů z oblasti inovací. Moravskoslezský a Ústecký kraj, které v České republice reprezentují př́iklad starých průmyslových regionů, dosahují poměrně dobrých výsledků v porovnání s ostatními kraji, což je možné považovat za znak relativně úspěšné ekonomické transformace. Naopak kraje s menší průmyslovou základnou a vyšším podílem agrárního sektoru, případně ohrožené růstem perifernosti území v rámci České republiky (př́hraniční i vnitřní), vykazuji nižší ekonomický a inovační rozvoj. Mezi tyto kraje patří Vysočina, Olomoucký, Karlovarský a Zlínský kraj.

\section{Závěr}

Vývojové trendy vobou oblastech vypovídají o změnách, kterým regionální ekonomiky České republiky prochází. Rozvíjení inovačního potenciálu v regionech se slabou inovační dynamikou, bude i za podpory $z$ veřejných zdrojů složité. $V$ těchto regionech je problémem nízká míra inovačního potenciálu, které se projevuje $\mathrm{v}$ celkově nízké rozvinutosti inovačního podnikání a sítě vědeckovýzkumných aktivit, horší vzdělanostní struktuře obyvatel. Tyto regionální rozdíly, v př́ípadě regionů s horšími makroekonomickými ukazateli (nižší HDP na obyvatele apod.), mají také větší vliv na přežívání určité míry duality $\mathrm{v}$ regionální ekonomice, která se $\mathrm{z}$ komerčního sektoru přenáší také do duality v oblasti inovačního podnikání a vědeckovýzkumných aktivit v podnikovém sektoru. 
Analýza dat potvrdila rozdíly v ekonomickém vývoji mezi strukturálně postiženými a hospodářsky zaostalými regiony, které se vzhledem k slabšímu ekonomickému potenciálu adaptují na ekonomické změny pomaleji, $v$ jejich př́padě lze očekávat i větší riziko růstu ekonomické diferenciace mezi úspěšnými a stagnujícími regiony.

Rozdíly mezi regiony v intenzitě růstu výdajů na VaV mezi roky 2005-2009 jsou poměrně výrazné, Regiony s nižšími objemy výdajů na počátku sledovaného období, které zároveň rostou rychleji, stále ještě nedosahují úrovně výdajů na $\mathrm{VaV}$ v regionech na průměrné úrovni. $\mathrm{V}$ tomto př́ípadě se prímo projevuje význam triple helix, tj. intenzivního zapojení univerzit do vývoje inovací, nebot' regiony s absencí inovačně zaměřených univerzit (Karlovarský kraj) nedisponují významným inovačním potenciálem, který by byl schopný získat finanční prostředky na vědecko-výzkumné aktivity.

$\mathrm{Na}$ druhou stranu se v ekonomice projevují pozitivní trendy v růstu inovačního podnikání, roste diverzifikace inovačních aktivit a schopnost firem kvalitativně zvyšovat úroveň své produkce, což otevírá nové možnosti pro rozvoj subdodavatelských vztahů nad rámec regionální a národní ekonomiky.

\section{Literatura}

[1] ASHEIM, B., COENEN, L. Contextualising Regional Innovation Systems in a Globalising Learning Economy: On Knowledge Bases and Institutional Frameworks. The Journal of Technology Transfer, 2006, Vol. 31, Iss. 1, pp. 163-173. ISSN 1573-7047. DOI: 10.1007/s10961-005-5028-0.

[2] BATHELT, H., MALMBERG, A., MASKELL, P. Clusters and Knowledge: Local Buzz, Global Pipelines and the Process of Knowledge Creation. Progress in Human Geography, 2004,Vol. 28, No. 1, SAGE Publications, pp.31-56. ISSN 0309-1325.

[3] BLAŽEK, J., CSANK, P. Nová fáze regionálního vývoje? Sociologický časopis, 2007, Vol. 43, No. 5, Praha, pp. 945-965. ISSN 0038-0288.

[4] BROSTROM, A. The Triple Helix: University-industry-government innovation in action. Papers in Regional Science, 2011, Vol. 90, Iss. 2, pp. 441-442, ISSN 1056-8190.

[5] BRISTOW, G. Resilient regions: re-'place'ing regional competitiveness. Cambridge Journal of Regions, Economy and Society, 2010, 3, pp. 153-167. ISSN 1752-1386.

[6] ETZKOWITZ H., LEYDESDORFF L. The dynamics of innovation: from National Systems and "Mode 2" to a Triple Helix of university-industry-government relations. Research Policy, 2000, Vol. 29, pp. 109 - 123. ISSN 0048-7333. DOI: 10.1016/S0048-7333(99)00055-4.

[7] GROOT,S. P.T., MÖHLMANN, J.L., GARRETSEN, J.H., DE GROOT, H.L.F. The crisis sensitivity of European countries and regions: stylized facts and spatial heterogenity. Cambridge Journal of Regions, Economy and Society, 2011, 4, pp. 437-456. ISSN 1752-1386.

[8] HASSINK, R. Regional resilience: a promising concept to explain differences in regional economic adaptability? Cambridge Journal of Regions, Economy and Society, 2010, 3, pp. 4558. ISSN 1752-1386.

[9] HLAVÁČEK, P., KOUTSKÝ, J. The Polarisation Tendencies in Localization of Foreign Direct Investments in the Czech Republic. In Liberec Economic Forum, 2011, p.186-194. ISBN: 97880-7372-755-0.

[10] HUGGINS, R, WILLIAMS, N. Entrepreneurship and regional competitiveness: The role and progression of policy. Entrepreneurship and regional development. 2011, Vol. 23, Iss. 9-10, pp. 907-32, 2011 ISSN: 0898-5626.

[11] JEŽEK, J. Městský marketing - koncepty, aplikace, kritická analýza. Ekonomický časopis, 2011, Vol. 59, No. 3, s. 243-258. ISSN 0013-3035.

[12] LEYDESDORFF, L., ZAWDIEB, G. The triple helix perspective of innovation systems. Technology Analysis \& Strategic Management, 2010, Vol. 22, No. 7, pp.789-804. ISSN 14653990. DOI: 10.1080/09537325.2010.511142.

[13] PIKE, A., DAWLEY, S., TOMANEY, J. Resilience, adaptation and adaptability. Cambridge Journal of Regions, Economy and Society, 2010, 3, pp. 59-70. ISSN 1752-1378. 
[14] RUMPEL, P., SLACH, O., KOUTSKY, J. Creative Industries in Spatial Perspective in the Old Industrial Moravian-Silesian Region. E \& M Ekonomie a Management, 2010, vol. 13, iss. 4, pp. 30-46. ISSN 1212-3609.

[15] RUTTEN, R., BOEKEMA, F. The Learning Region: Foundations, State of the Art, Future. Edward Elgar Publishing Limited, Cheltenham, 2007, p. ISBN 1843769387.

[16] TÖDTLING F, TRIPPL, M. One size fits all?: Towards a differentiated regional innovation policy approach. Research Policy, 2005, Vol. 34, Iss. 8, pp. 1203-1219. ISSN 0048-7333. DOI: 10.1016/j.respol.2005.01.018.

[17] TOUŠEK, V., NOVÁK, V: Ekonomická krize a trh práce české republice. Regionální studia, 2012, 1, str. 38-52. ISSN 1803-1471.

[18] VITURKA, M. Regional disparities and their evaluation in the context of regional policy. Geografie, 2010, Vol. 115, No. 2, pp. 131-143.ISBN 1212-0014.

[19] WOKOUN, R., Regional Competitiveness And Regional Development Factors In The Czech Republic, In Bucek M; Capello R; Hudec O; et al. (eds.) Conference: 3rd Central European Conference in Regional Science, 2009, Kosice, ISBN 978-80-553-0363-5.

[20] Resilience Capacity Index Institute for Governmental Studies, The University of Berkeley, Dostupné z http://brr.berkeley.edu/rci/, (cit. 25. 4. 2013). 